Journal of Business \& Management (COES\&RJ-JBM)

ISSN (E): 2306-7179 ISSN (P): 2306-8043

Publisher: Centre of Excellence for Scientific \& Research Journalism, COES\&RJ LLC

Online Publication Date \& Issue: 1st January 2018, Vol.6, No.1, January 2018

https://doi.org/10.25255/jbm.2018.6.1.23.45

\title{
Adoption of e-banking technology: \\ Basis of creating network infrastructure and marketing strategies in region 3
}

\author{
Bernandino P. Malang, DBA \\ Ferdinand C. Somido, PhD \\ Susana C. Bautista, EdD \\ Pedrito Jose V. Bermudo, PhD \\ Antonio D.Yango, PhD \\ Leomar S. Galicia, PhD
}

\begin{abstract}
:
The main goal of this descriptive-correlational study was to assess different factors involved towards adoption of e-banking technology among consumers in different provinces in region 3 of the Philippines as a basis for creating network infrastructure andmarketing strategies to help the families or individuals to go e-banking technologies. The results of the analysis showed that the regression model (consisting of technological, organizational, and environmental factors) does not significantly predictthe respondents' perception on e-banking services' reliability, convenience, speed, safetyand security, user-friendliness, cost-effectiveness, error-freeness. Additionally, therespondents considered two of the nine given scenarios as challenges in their adoption of e-banking technologies: (1) their fear about the possible occurrence of electronic crimes and (2) the customers' preference for face-to-face banking. The improvement of Internet connection and the conduct of trainings ororientation regarding e-banking services by banking institutions are recommended by theresearcher in addition to the proposed network infrastructure and marketing strategies to be considered by the bank to be able to educate customers in adopting e-banking technology.

Keywords:

e-banking technology, network infrastructure, marketing strategies

Citation:

Malang, Bernandino P.; Somido, Ferinand C.; Bautista, Susana C.; Bermudo, Pedrito Jose V.; Yango, Antonio D.; Galicia, Leomar S. (2018); Adoption of e-banking technology: Basis of creating network infrastructure and marketing strategies in region 3; Journal of Business \& Management (COES\&RJ-JBM) Vol.6,No.1,pp.23-45, https://doi.org/10.25255/jbm.2018.6.1.23.45.
\end{abstract}

This work is licensed under a Creative Commons Attribution 4.0 International License. 


\section{Introduction}

The fast evolution of e-banking technologies has had a remarkable impact on how banks operate their business and the way in which consumers conduct their banking activities (Tarhini, 2015). Adopting electronic (i.e., internet) banking, customers have now the option to perform banking activities such as paying bills, checking account information and transferring funds remotely anytime (Abu-Shanab, 2007, Xue, 2011, Yousafzai, 2012). In addition, there are also numerous benefits for banks in adopting and incorporating use of e-banking banking such as cost-savings, increase service quality and increase their revenues (Chandio, 2013).

Region 3 or Central Luzon covers the provinces of Bulacan, Pampanga, Tarlac, Nueva Ecija, Bataan, Zambales and Aurora. It has a total land area of 2,215,752 hectares. The region is endowed with a balanced mix of environmental assets to value, maintain, develop and manage accordingly. It is composed of 494,533 hectares of forestland, 251,518 hectares of protected areas composed of watersheds and forest reserves, national parks, games refuge, bird sanctuary and wildlife area covering $13.8 \%$ of the region's land area. Forty one percent of its land area is composed of agricultural plains with rice as its main crop. Long coastlines rich with fishing grounds border it. Mineral resources may be extracted in Bulacan and Zambales Central Luzon is traditionally known as the Rice Bowl of the Philippines due to its vast rice lands that produces most of the nation's staple food products as well as a wide variety of other crops. With the opening of various investment opportunities in Economic Zones in Clarkfield and Subic Bay Area, Region III is now termed as the W-Growth Corridor due to the industrialization of many areas in the region. The W-Growth Corridor covers areas with rapid growth potentials for the industrial, tourism and agricultural sectors of Central Luzon, making Region III one of the most critical regions in terms of environmental concerns primarily due to the rapid sprawl of industries/establishments and human settlements while the necessary land use and environmental planning are not yet effectively being carved. Also, situated in the region are the special economic and industrial zones like the Luisita Industrial Park (LIP) in Tarlac City, Subic Bay Freeport Zone (SBFZ) in Olongapo City, Authority for the Freeport Area of Bataan (AFAB) in Mariveles, Bataan and Clark Freeport Zone (CFZ) in Angeles City. Tarlac, Bulacan and Nueva Ecija had developed a large percentage of land for agricultural research, piggery and poultry projects. The said projects contribute much to the pollution load in the water bodies. In Zambales and Bataan, dominant are operations of beach resorts and tourism projects.

Banking has always been a highly information intensive activity that relies heavily on Information Technology (IT) to acquire, process, deliver the information to relevant users. Not only IT is critical in processing information, it provides a way for the banks to differentiate their products and services. Banks finds that they have to constantly innovate and update to retain their demanding and discerning customers and to provide convenient, reliable and convenient services. With the rapid diffusion of the internet, banking in cyberspace is fast becoming an alternative channel to provide banking services and products.

According to GMA News dated February 12, 2014, Philippines has a comprehensive banking system encompassing various types of banks, from large universal banks to small 
rural banks and even non-banks. As at 17 February 2014, there were 36 universal and commercial banks, 71 thrift banks, 533 rural banks, 40 credit unions and 6,267 non-banks with quasi-banking functions, all licensed with the Bangko Sentral ng Pilipinas (Central Bank of the Philippines) under Republic Act No. 8791, also known as the General Banking Act of 2000. Today, Central Luzon is among the most progressive regions in the Philippines. Region 3 is served by all major banks with more than 200 banks doing business in the region. Despite the many benefits of e-banking, still various problems need to be addressed before it can become fully implemented and widely adopted.

The main goal of this study was to assess different factors involved towards adoption of e-banking technology among consumers in different provinces in region 3 as basis for creating network infrastructure and marketing strategies to help the families or individuals to go e-banking technologies. Specifically, the researchers sought answers to the following questions: What are the respondents' demographic profile in terms of the following: age, gender, nature of work as to: employed or SME owner: In what aspects can the consumers assess the electronic banking services as to the following factors: reliability, ease of use/ convenience, speed, safety and security, user friendliness, cost effectiveness, and error freeness: Is there a significant difference in the respondents' assessment on electronic banking services as to reliability, ease of use/ convenience, speed, safety and security, user friendliness, cost effectiveness, and error freeness across age, gender and nature of work groups : Is there a significant relationship that contribute/influence adoption of e-banking between respondents' assessment on electronic banking services as to aforementioned factors across the following critical factors: technological, Organizational, and Environment? What are the challenges facing the adoption of e-banking technologies? What are the recommendations offered by the respondents in the challenges facing the adoption of e-banking technologies: and What proposed network infrastructure and promotional campaign that the bank will use to adopt e-banking technologies in the region 3 ?

Most related research studies and literatures cast the problem statement within the context of a framework. The IPO or Input-Process-Output Model was used in this study. In this model, a process is viewed as a series of boxes connected by inputs and outputs. This IPO model provides the general structure and guide for the direction of the study.

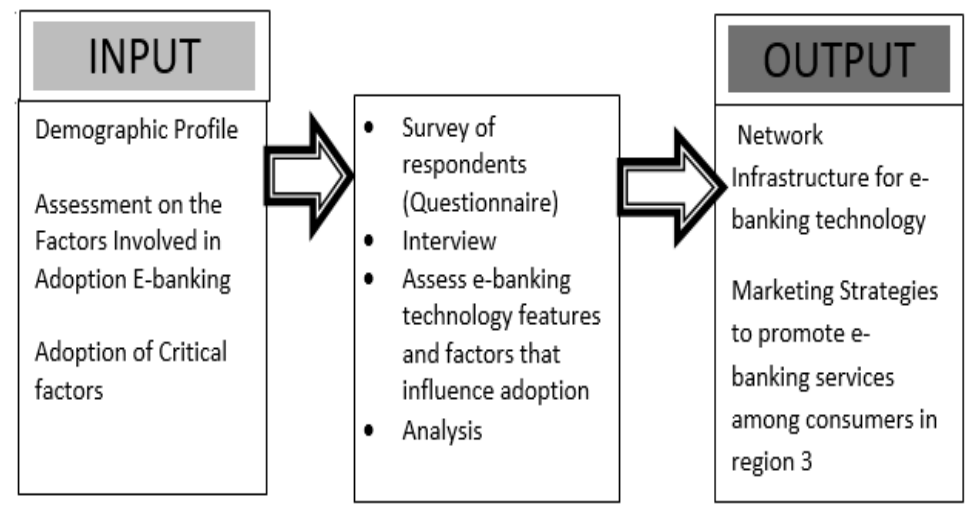

Figure 3.0 Paradigm of Research 


\section{Methods}

This study used the descriptive method of research using questionnaires as the main source of data. This method was used because the researcher believed that it will give a complete analysis and report on the adoption of e-banking technologies among consumers in region 3.The term descriptive research refers to the type of research question, design, and data analysis that will be applied to a given topic. The type of question asked by the researcher will ultimately determine the type of approach necessary to complete an accurate assessment of the topic at hand. Descriptive studies, primarily concerned with finding out "what is". It is concerned with the point of view or attitudes that are held processes that are going on. Descriptive studies are of large value in providing facts on which scientific judgment is based. They play a great role in the development of instrument for measurement of many things, instrument that are employed in all types of quantitative research. It relates to the conditions or relationships, opinions held and processes going on, effects that are evident or trends that are developing. It is primarily concerned with the present, although it often considers past events and influences as they relate to current conditions. (Best and Khan: 1998).

The first criterion used to get the targeted sample were the bank customers who have savings account and basic checking accounts whose bank provides Internet banking service, who have access to Internet and who know how to use the internet. The sample for conducting the survey contains customers from the different Small and Medium Enterprises (SME's) in the different provinces in region 3. The study covered bank customers from Bulacan, Pampanga, Bataan, Nueva Ecija, Tarlac, and Zambales and Aurora.

The researchers used the purposive sampling because the researchers wanted to distribute the instrument to specific respondents only. The respondents were the customers who are employed in any business organization with current savings or checking account in any banks in region 3. Furthermore, selected owners of SME's in region 3 are also part of respondents since they are personally exposed in transacting business especially in financial transaction. The total number of respondents were one hundred (100) customers of banks in which the researcher believed that the statistical point of view was sufficient to be included in the study.

The profile of the respondents was categorized as to age, gender, and nature of work. Majority or (87\%) of the respondents are in their early and middle adulthood aging from 21 to 50 years old. Furthermore, there were only eleven or $11 \%$ aging 51 to 60 , while only two respondents or $2 \%$ aging above 60 years old. The respondents of the study were forty two (42) or $42 \%$ male respondents while fifty eight (58) or $58 \%$ are female. The number of respondents is equally distributed in terms of the nature of work. Half of the respondents are employed in educational institution, government agencies, private companies and others, while the other half are owners of small and medium enterprises including farmers. 
The questionnaires formulated by the researchers was used in this study which was distributed through courier system, e-mail and other social networking sites like facebook, while others was hand-carried.

The researchers relied on the responses of the subject to the questionnaire. The first part of the questionnaire shall contain questions about personal information of the respondents. Structured questionnaire containing forty (40) items was developed for Part 2 to determine respondents' perception of the electronic banking services. All items were measured by a response on a 5-point likert scale in agreement, ranging from one (1) strongly disagree and five (5) strongly Agree. Also, another structured questionnaire containing nine (9) items was developed for Part 3 to determine the respondents' perception on the different challenges facing the adoption of e-baking technologies. Furthermore, to identify the factors that influenced adoption of e-banking, another thirteen (13) structured questions was developed to get the feedback from the respondents. Finally, a checklist of statements was provided for the respondent in Part 5 to determine the recommendations offered by respondents on the different challenges.

The questionnaire was subjected to validation by administering it to purposively selected ten (10) trial respondents from bank customers and one (1) from bank employee who was not included in the final administration of data. Furthermore, the dry run was conducted to ascertain the administration of the questionnaire, the clarity of the contents, and the procedures, and the instruction that will be taken in the conduct of the final copy. All comments and suggestions that were given by the trial respondents which were incorporated in the final copy of the questionnaire. Then, the revised questionnaire was reproduced and distributed to the target respondents of the study.

\section{Results}

1: What are the respondents' demographic profile in terms of age, gender and nature of work group be described?

Table 1

Respondents' Demographic Profile

\begin{tabular}{lll}
\hline \multicolumn{1}{c}{ Demographic Profile } & $F$ & $\%$ \\
\hline Age & 33 & 33 \\
$21-30$ & 26 & 26 \\
$31-40$ & 28 & 28 \\
$41-50$ & 11 & 11 \\
$51-60$ & 2 & 2 \\
Above 60 & 42 & 42 \\
Gender & 58 & 58 \\
$\quad$ Male & \\
Female & 50 & 50 \\
Nature of Work & 50 & 50 \\
Employed & & \\
SME & & \\
\hline
\end{tabular}

As shown in Table 1, the data revealed that majority (59\%) of the respondents are in their early and middle adulthood aging from 21 to 40 and female. On the one hand, the 
number of respondents is equally distributed in terms of the nature of work. Half of the respondents are employed while the other half are owners of small and medium enterprises.

2: In what aspects can consumers assess electronic banking services in terms of their reliability, ease of use, convenience, speed, safety and security, user friendliness, cost effectiveness, and error freeness?

Table 1

Overall Assessment of Electronic Banking Services

\begin{tabular}{|l|c|c|c|}
\hline \multicolumn{1}{|c|}{ Constructs } & WM & VI & Rank \\
\hline Reliability & 3.91 & Agree & 1 \\
\hline Convenience & 3.78 & Agree & 4 \\
\hline Speed & 3.72 & Agree & 5 \\
\hline Safety & 3.69 & Agree & 6 \\
\hline User-friendliness & 3.89 & Agree & 2 \\
\hline Cost-effectiveness & 3.56 & Agree & 7 \\
\hline Error-freeness & 3.79 & Agree & 3 \\
\hline Overall & $\mathbf{3 . 7 7}$ & Agree & \\
\hline
\end{tabular}

As can be derived from table 1, the mean scores of all constructs of the perception of ebanking services suggest that the respondents have a positive view about e-banking services. As shown in the table, the over-all composite mean is 3.77 , which means Agree.

Reliability ranked 1, with a weighted mean of 3.91. This was followed by Userfriendliness with a weighted mean of 3.89 , followed by Error-freeness then by Convenience. Safety ranked 6, while cost-effectiveness ranked 7. This last two indicators have a weighted mean of 3.69 and 3.56 respectively.

This was supported by the research conducted by Alsoufi \& Ali (2014) entitled: Customers' Perception of M-Banking Adoption in Kingdom of Bahrain: An Empirical Assessment of an Extended TAM Model. It was found that perceived usefulness strongly affected by customer service, with standardization coefficient of 0.389 , and efficient transaction factor, with standardization coefficient that equals to 0.325 . As well as, perceived ease of use affected strongly by compatibility, about 0.460 standardization coefficient, and self-efficacy with standardization coefficient of 0.255 . Moreover, perceived usefulness and perceived ease of use are affecting intention to use directly and strongly, in which perceived ease of use (standardization coefficient $=0.442$ ) has more impact than perceived usefulness (standardization coefficient $=0.287$ ). The other factors such as perceived cost (Standardization coefficient= -0.059) and perceived risk (Standardization coefficient $=-0.091$ ) have no effect on the intention to use mobile banking directly, but affecting indirectly through examined the relationship with perceived usefulness and ease of use. Only perceived risk has indirect relationship with intention to use through perceived usefulness (standardization coefficient $=0.403$ ) and perceived ease of use (Standardization coefficient=0.432). 
3. Is there a significant difference between respondents' assessment of reliability, ease of use, speed, safety and security, user friendliness, cost effectiveness and error freeness on electronic banking services across age, gender and nature of work groups?

A one-way between-groups analysis of variance was conducted to determine whether there is a significant difference among the respondents' perception on the reliability, convenience, speed, safety and security, users friendliness, cost effectiveness and error freeness of online banking services across age groups. Subjects were divided into five groups according to age (Group 1: 21 to 30 years old; Group 2: 31 to 40 years old; Group 3: 41 to 50 years old; Group 4: 51 to 60 years old; Group 5: Above 60 years old).

Table 2

Analysis of Variance Results (Overall Perception on Online Banking Services)

\begin{tabular}{lrrrrr}
\hline & Sum of Squares & df & Mean Square & $F$ & Sig. \\
\hline Between Groups & 1.497 & 4 & .374 & 1.201 & .315 \\
Within Groups & 29.590 & 95 & .311 & & \\
Total & 31.086 & 99 & & & \\
\hline
\end{tabular}

The overall perceptions on online banking services of the respondents from different age groups do not significantly differ $[F(4,95)=1.201, p=.315)$.

Table 3

Two-Sample Z-Test Results (Between Male and Female Respondents)

\begin{tabular}{lrrrr}
\hline & Z & Df & Sig. (2-tailed) & Decision \\
\hline Reliability & -1.758 & 198 & .220 & Accept Ho \\
\hline Convenience & .574 & 198 & .568 & Reject Ho \\
\hline Speed & .330 & 98 & .742 & Accept Ho \\
\hline Safety & -.760 & 98 & .449 & Accept Ho \\
\hline User-friendliness & .178 & 98 & .859 & Accept Ho \\
\hline Cost-effectiveness & -.187 & 98 & .852 & Accept Ho \\
\hline Error-freeness & .631 & 98 & .530 & Reject Ho \\
\hline Overall & -.116 & 98 & .908 & Accept Ho \\
\hline
\end{tabular}

A two-sample z-test was conducted to compare the assessment of male and female respondents on online banking services in terms of reliability convenience, speed, safety, user-friendliness, cost-effectiveness, and error-freeness. The total combined scores of the male and female in these seven areas were also compared.

The results of the analysis revealed the following:

1. It is observed that comparing the assessment of male and female respondents on online banking services to determine the following factors: has no significant difference on reliability as calculated with $z$-value of -1.569 which is lesser than the critical value of .120 , speed with computed $z$-value of .330 which is lesser than the critical value of .742 , 
safety and security with computed z-value of -.760 which is lesser than the critical value .449 , user-friendliness with computed $z$-value of -.178 which is lesser than the critical value .859 , and cost-effectiveness with computed $z$-value of -.187 which is lesser than the critical value .852 , in .05 level of significance, therefore the null hypothesis is accepted. Therefore, gender (male or female) does not significantly difference in the perception of reliability, safety and security, user friendliness, and cost effectiveness of ebanking technology.

2. It is observed that comparing the assessment of male and female respondents on online banking services to determine the following factors: has significant difference on Convenience with computed z-value of .574 which is greater than the critical value .568 and Error-freeness with computed z-value of .631 which is greater than the critical value .530 in .05 level of significance, therefore the null hypothesis is rejected. Therefore, gender (male or female) have significantly difference in their perception on convenience and error-freeness of e-banking technology.

Aside from gender, the present study also explored whether or not the respondents' assessment about the online banking services differ depending on the respondents' nature of work (i.e. small or medium enterprise owner or employed).

Table 4

Two-Sample Z-Test Results Between SME Owners and Employed

\begin{tabular}{lrrrr}
\hline & $\mathrm{z}$ & $\mathrm{df}$ & Sig. (2-tailed) & Decision \\
\hline Reliability & .882 & 98 & .380 & Reject Ho \\
Convenience & 1.280 & 98 & .204 & Reject Ho \\
Speed & 1.805 & 98 & .074 & Reject Ho \\
Safety & .904 & 98 & .368 & Reject Ho \\
User-friendliness & .644 & 98 & .521 & Reject Ho \\
Cost-effectiveness & .443 & 98 & .659 & Accept Ho \\
Error-freeness & 1.260 & 98 & .211 & Reject Ho \\
Overall & 1.266 & 98 & .208 & Reject Ho \\
\hline
\end{tabular}

The assessment of respondents (who are labeled as either SME owners or employed) on online banking services were compared using an two-sample z-test. Their mean scores in the seven areas of evaluation (such as reliability, convenience, speed, safety, userfriendliness, cost-effectiveness, and error-freeness) and their overall mean scores were analyzed.

The findings are as follows:

1. There is significant difference in the assessment on reliability of online banking services of SME owners and employed with computed z-value of .574 which is greater than the critical value 568, in .05 level of significance, therefore null hypothesis is rejected.

And SME owners $(M=3.86, S D=.63)$ and employed $(M=3.97, S D=.62, p=.380)$. The magnitude of difference in the means is very small (eta squared $=.008$ ). Please refer to attached Appendix for Group Statistics Results (Nature of Work and Constructs of Assessment on Online Banking). 
2. There is significant difference in the assessment on convenience of online banking services of SME owners and employed with computed z-value of 1.280 which is greater than the critical value .204, in .05 level of significance, therefore null hypothesis is rejected.

And SME owners $(M=3.69, S D=.73)$ and employed $(M=3.88, S D=.76, p=.204)$. The magnitude of difference in the means is small (eta squared= .016). Please refer to attached Appendix for Group Statistics Results (Nature of Work and Constructs of Assessment on Online Banking).

3. There is significant difference in the assessment on speed of online banking services of SME owners and employed with computed z-value of 1.805 which is greater than the critical value .074 , in .05 level of significance, therefore null hypothesis is rejected.

And SME owners $(M=3.60, S D=.61)$ and employed $(M=3.83, S D=.66, p=.074)$. The magnitude of difference in the means is small (eta squared $=.032$ ).

4. There is significant difference in the assessment on safety and security of online banking services of SME owners and employed with computed z-value of .904 which is greater than the critical value .368, in .05 level of significance, therefore null hypothesis is rejected.

And of SME owners ( $M=3.63, S D=.61)$ and employed $(M=3.75, S D=.72, p=.368)$. The magnitude of difference in the means is very small (eta squared $=.008$ ).

5. There is significant difference in the assessment on user-friendliness of online banking services of SME owners and employed with computed z-value of .644 which is greater than the critical value .521, in .05 level of significance, therefore null hypothesis is rejected.

And SME owners $(M=3.84, S D=.63)$ and employed $(M=3.93, S D=.71, p=.521)$. The magnitude of difference in the means is very small (eta squared $=.004$ ).

6. There is no significant difference in the assessment on cost-effectiveness of online banking services f SME owners and employed with computed z-value of .443 which is greater than the critical value .659, in .05 level of significance, therefore null hypothesis is rejected.

And SME owners $(M=3.54, S D=.43)$ and employed $(M=3.59, S D=.67, p=.659)$. The magnitude of difference in the means is very small (eta squared $=.002$ ).

7. There is significant difference in the assessment on error-freeness of on-line banking services of SME owners and employed with computed z-value of 1.260 which is greater than the critical value .211 , in .05 level of significance, therefore null hypothesis is rejected.

And SME owners $(M=3.69, S D=.69)$ and employed $(M=3.89, S D=.85, p=.211)$. The magnitude of difference in the means is small (eta squared $=.016$ ).

8. There is significant difference in the overall assessment of online banking services of SME owners and employed with computed z-value of 1.266 which is greater than the critical value .208 , in .05 level of significance, therefore null hypothesis is rejected.

And SME owners $(M=3.70, S D=.52)$ and employed $(M=3.84, S D=.60, p=.208)$. The magnitude of difference in the means is small (eta squared $=.016$ ). 
4. Is there a significant relationship that contribute/influence adoption of e-banking between respondents' assessment on electronic banking services as to aforementioned factors across the following critical factors: technological, organizational, and environment?

Tables 5, 6, 7 and 8 present the respondents' assessed Overall assessment of E-banking services (dependent variable) by their assessment $\mathrm{n}$ about the critical factors (technological, organizational, environmental) that contribute to their adoption of Ebanking.

Table 5

Descriptive Statistics (Overall Perception)

\begin{tabular}{lccc}
\hline & Mean & Std. Deviation & $\mathrm{N}$ \\
\hline Overall Perception & 3.77 & .560 & 100 \\
Technological Factor & 3.06 & .868 & 100 \\
Organizational Factor & 3.03 & .929 & 100 \\
Environmental Factor & 3.52 & .875 & 100 \\
\hline
\end{tabular}

Table 6

Model Summary of the Relationship of Respondent's Overall Assessment to the three Critical Factors

\begin{tabular}{lcccc}
\hline Model & $\mathrm{R}$ & $\mathrm{R}$ Square & Adjusted R Square & $\begin{array}{c}\text { Std. Error of the } \\
\text { Estimate }\end{array}$ \\
\hline 1 & $.095^{\mathrm{a}}$ & .009 & -.022 & .5664887 \\
\hline . Predictors: (Constant), Environmental, Organizational, Technological & \\
b. Dependent Variable: Overall Assessment & &
\end{tabular}

Table 7

Analysis of Variance (Overall Assessment)

\begin{tabular}{llccccc}
\hline Model & & Sum of Squares & Df & Mean Square & $F$ & Sig. \\
\hline 1 & Regression & .279 & 3 & .093 & .290 & $.833^{\text {a }}$ \\
& Residual & 30.807 & 96 & .321 & & \\
& Total & 31.086 & 99 & & & \\
\hline
\end{tabular}

a. Predictors: (Constant), Environmental, Organizational, Technological

b. Dependent Variable: Overall Perception

Table 8

Coefficients (Overall Assessment)

\begin{tabular}{lcccccc}
\hline & \multicolumn{2}{c}{$\begin{array}{l}\text { Unstandardized } \\
\text { Coefficients }\end{array}$} & $\begin{array}{c}\text { Standardized } \\
\text { Coefficients }\end{array}$ & & \\
Model & $\mathrm{B}$ & Std. Error & Beta & t & Sig. \\
\hline 1 (Constant) & 3.931 & .257 & & 15.270 & .000 \\
\hline
\end{tabular}




\begin{tabular}{lrlrrr} 
Technological Factor & -.070 & .095 & -.109 & -.741 & .461 \\
Organizational Factor & .006 & .086 & .011 & .074 & .941 \\
Environmental Factor & .010 & .078 & .016 & .131 & .896 \\
\hline
\end{tabular}

Note: Dependent Variable: Overall Perception of E-banking Services

A multiple linear regression was calculated to predict overall assessment of respondents about e-banking service based on perceived technological, organizational, and environmental factors. There was no significant regression equation found $(F(3,96)$ $=.290, p=.833$ ), with an $R^{2}$ of .009 . The three factors were not significant predictors of participants' overall assessment about e-banking services.

Research Question No. 5: What are the challenges in the adoption of e-banking technologies?

Table 9

Challenges in the Adoption of E-banking Technologies

\begin{tabular}{|l|c|c|c|}
\hline \multicolumn{1}{|c|}{ Indicators } & WM & VI & Rank \\
\hline The cost of adoption is very high. The services are too expensive. & 3.12 & NS & 9 \\
\hline For many customers, traditional banking still remains the best option. & 3.52 & NS & 4 \\
\hline Many customers are technologically illiterate. & 3.37 & NS & 7 \\
\hline Lack of infrastructure is the main problem. & 3.51 & NS & 5 \\
\hline $\begin{array}{l}\text { Most of the customers do not know how to use and are not aware of some } \\
\text { E-banking services provided by their banks. }\end{array}$ & 3.53 & NS & 3 \\
\hline \begin{tabular}{l|c|} 
E-banking services generally do not have privacy of customer's information. \\
Most of the customers prefer face to face banking.
\end{tabular} & 3.34 & NS & 8 \\
\hline $\begin{array}{l}\text { Most of the customer's banks are providing few e-banking services and some } \\
\text { have not yet adopted e-banking services. }\end{array}$ & 3.72 & $\mathrm{~A}$ & 2 \\
\hline Customers fear using e-banking because electronic crimes are arising greatly. & 3.73 & NS & 6 \\
\hline & $\mathbf{3 . 4 8}$ & $\mathbf{N S}$ & 1 \\
\hline
\end{tabular}

Out of 9 identified challenges in the adoption of E-banking technologies, the respondents agreed on only two [number $9(M=3.73, S D=1.15)$ and number $7(M=3.72, S D=.975)]$. The fear about the possible occurrence of electronic crimes seems to be a valid hindrance for individuals to engage in e-banking. Perhaps, the respondents' assessment about the said challenge has been influenced by what they see on the television, hear on the radio or read on the newspapers.

On the one hand, the respondents do not seem to be certain about the other seven (7) given situations as to whether they can be considered as challenges or not.

It is supported in the study of Munyoki, J. (2011) which showed that banks had only partially adopted e-banking as a strategy. The issue of security was found to be the most critical factor influencing e-banking adoption. Other major inhibitors were inadequate regulatory support, lack of in-house it professionals and quality of infrastructure. 
6. What are the recommendations offered by the respondents in the challenges facing the adoption of e-banking technologies?

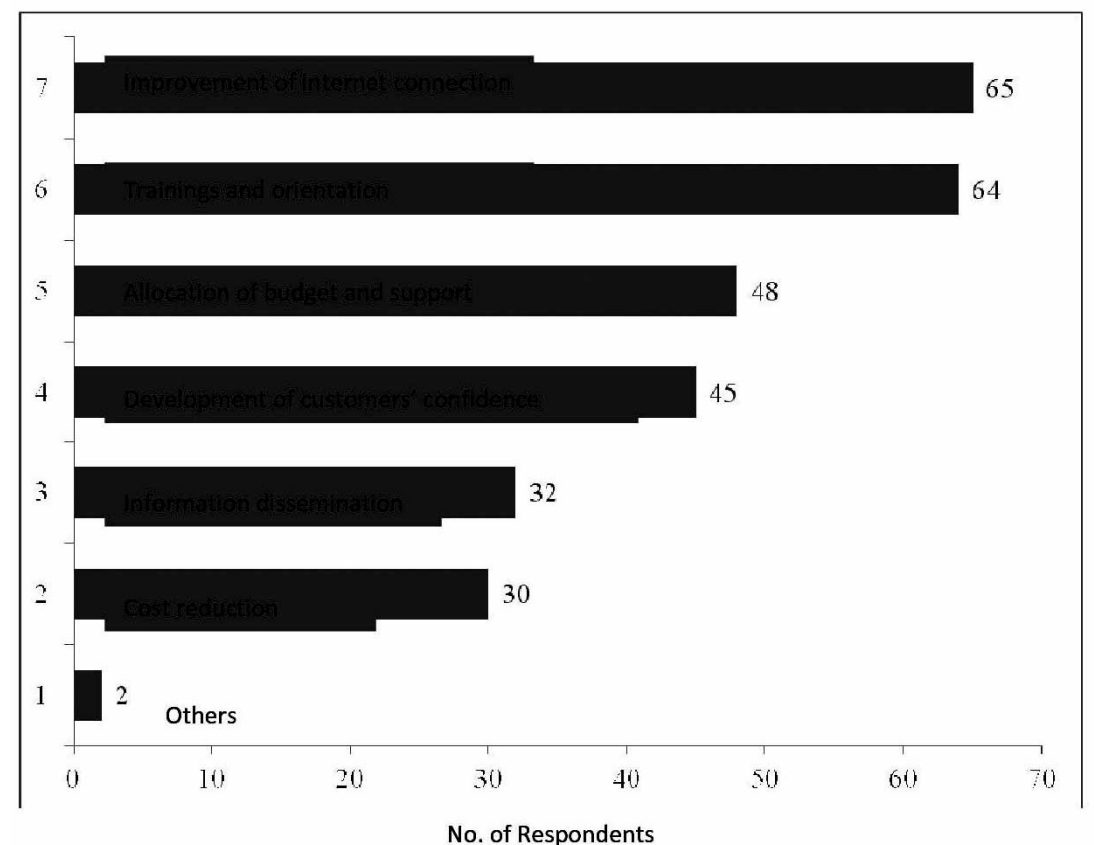

Figure 4. Recommendations to overcome challenges in adopting e-banking services.

It can be viewed from figure 4 that the top recommendation given by the majority of the respondents is the improvement of Internet connection (65\%). This is followed by the recommendation that banking institutions must conduct trainings or orientation regarding e-banking services (64\%), that government should allocate budget for the IT infrastructure and support the banking industries (48\%), that the confidence of customers in adopting e-banking services must be developed (45\%), that the information about e-banking services must be disseminated from the municipality level to barangay level (32\%), and that banking institutions must reduce e-banking services costs (30\%). On the one hand, two other suggestions were given: (1) that the e-banking site must be more accessible particularly to senior citizens and (2) that the internet connection must be able to respond well to the internet banking facility. It can be noted that this second suggestion is related to the top recommendation. Further, the top two recommendations have something to do with the service infrastructures that the banking industry must be able to enhance in order to give good quality services to the clienteles.

7. What proposed network infrastructure and promotional campaign that the bank will use to adopt e-banking technologies in the region 3 ?

The growth of high speed networks, coupled with the falling cost of computing power, is making possible applications undreamed of in the past. Voice, data, images, and video may now be transferred around the world in micro-seconds. This explosion of technology is changing the banking industry from paper and branch banks to' digitized and networked banking services. It has already changed the internal accounting and 
management systems of banks. It is now fundamentally changing the delivery systems banks use to interact with their customers. All over the world, banks are still struggling to find a technological solution to meet the challenges of a rapidly-changing environment. It is clear that this new technology is changing the banking industry forever. Banks with the ability to invest and integrate information technology will become dominate in the highly competitive global market.

In line with the new challenges in banking institutions, the researcher proposed a new network infrastructure designed for a bank in Central Luzon. The main goal of the network infrastructure is to allow the bank to use better network infrastructure for a better delivery of banking products and services for more conveniently and effectively than ever before - thus creating new bases of competition.

The data and communications networks are essential to bank operations. With the proliferation of mobile technology and connectivity, new platforms emerged for electronic payments, giving rise to new service-delivery models that can connect disparate markets and communities.

To meet the unique communications requirements of financial institutions and their consumers, the proposed network infrastructure gives you the ability to communicate and provide consumers with secure, managed in-branch wireless connectivity in central luzon.

The main Internet Service Provider (ISP) for the model is PLDT / COMCLARK. (See figure 5). Some of the hardware requirements needed for the model are the following: modem, wireless router, VOIP server, web server, domain controller, network printer, and data switch. 


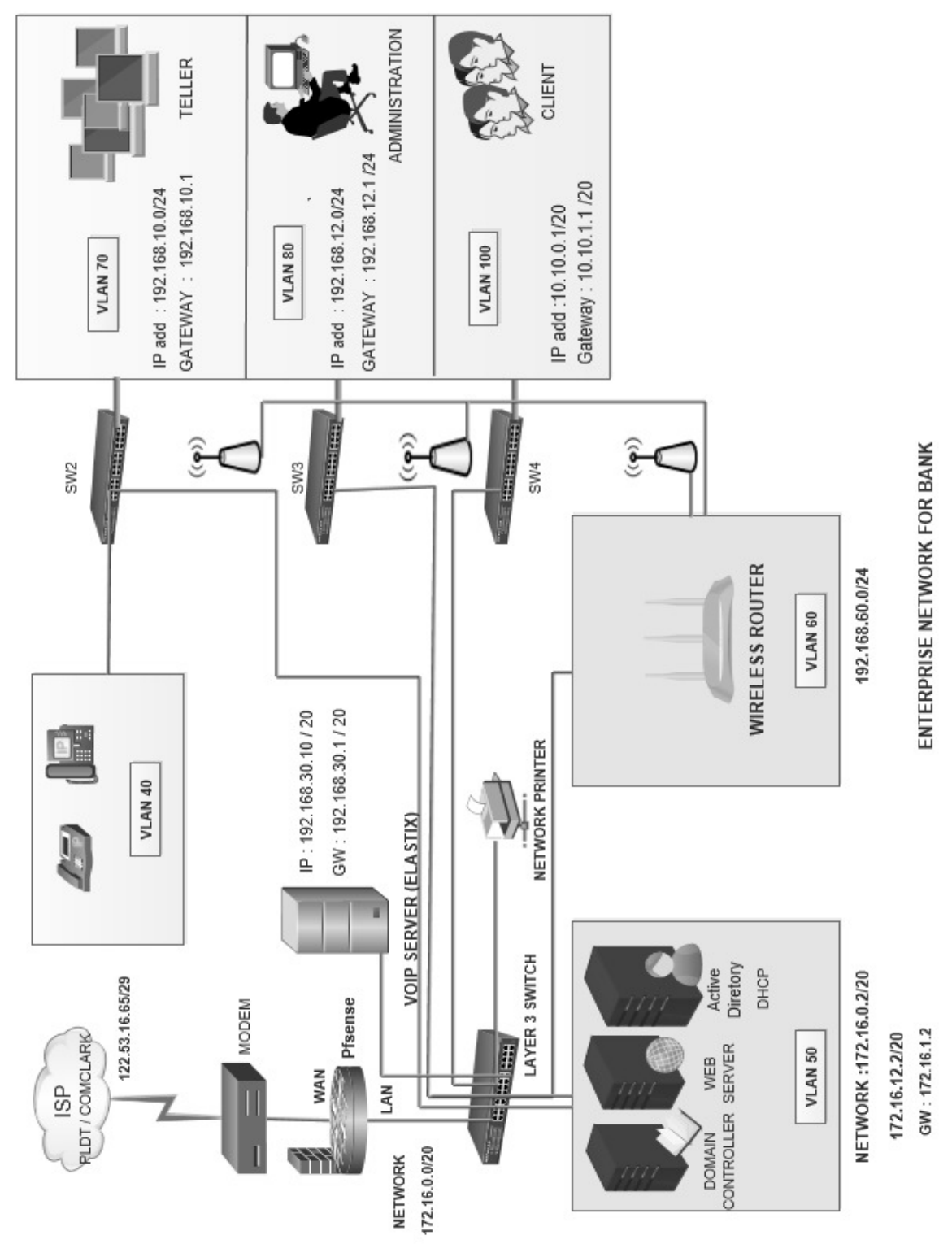

Figure 5.0 Proposed Network Infrastructure for a bank

\section{ADOPTION OF E-BANKING TECHNOLOGY:}

Banks should seek to collaborate with internet service providers (ISP) so as to gain high quality internet infrastructure to enable the banks offer better quality services and at the same time enhance internet accessibility.

The major advantages for the bank to implement IT infrastructure are:

- Availability of a wide range of inquiry facilities, assisting the bank in business development and follow-up. 
- Immediate replies to customer queries without reference to ledger-keeper as terminals are provided to Managers and Chief Managers.

- Automatic and prompt carrying out of standing instructions on due date and generation of reports.

- Generation of various MIS reports and periodical returns on due dates.

- Fast and up-to-date information transfer enabling speedier decisions, by interconnecting computerized branches and controlling offices.

There are four fundamental ways in which digital capabilities can be used by banks to create value.

First, digital technologies increase a bank's connectivity-not just with customers but also with employees and suppliers. This extends from online interactivity and payment solutions to mobile functionality and opportunities to boost bank brands in social media.

Second, digital draws on big data and advanced analytics to extend and refine decision making. Such analytics are being deployed by the most innovative banks in many areas, including sales, product design, pricing and underwriting, and the design of truly amazing customer experiences.

Finally, new infrastructure is a means of fostering innovation across products and business models.

\section{MARKETING STRATEGIES TO PROMOTE E-BANKING SERVICES}

The coming of e-banking technology has opened a lot of opportunities in many sectors and industries in the world not only in the Philippines. Banking industry can explore techniques and strategies that they can use on the cyberspace that will support and enhance the bank's generally marketing objectives. It helps the bank to improve awareness to their target audience. E-banking is considered as a competitive field. This gives a lot of clients to transact without the need to go to the bank personally. Online banking is now becoming as one of the newest options of busy people who don't have the time. Marketing strategy of online banking is also very significant.

1. The use of Social Media. One of the best marketing strategies is to use the Social Media. Customers are smartphone users, making them a great target audience for the benefits of e-banking technology. Make sure your Facebook and other social pages are optimized for mobile viewing and they include easy links to your e-banking services.

2. Blogging. This is one of an ideal marketing strategies of e-banking. In order to do this, they will make an attractive or informative article that can be useful to the users. By this way, it can help them to be noticed especially if the user becomes interested in trying ebanking.

3. Search Engine Optimization (SEO). The goal of SEO is to be there when people are looking for you. Think for a moment about the products you sell-such as loans, checking/savings accounts and mortgages. Before customers make a purchase, they are spending their time researching options and learning more about the product. Think about what you would do if you were interested in refinancing a mortgage. Chances are, you would begin by searching: 'home refinancing rates'. In SEO, your goal is to be there to answer these questions for customers online so that they trust you and view you as 
the financial leader with whom they want to do business. As a financial institution, your goal should be to be on the first page of Google search results when someone searches for banks in your city.

4. SMS Text. Many financial institutions are beginning to ask for mobile phone numbers as part of the new account opening process to enable better communication with customers.

5. Email. An email campaign is a great way to target e-banking customers. Some banks are even targeting customers who use the branch extensively for check deposits, promoting the remote deposit capture function of mobile banking. The key with any email campaign, however, is providing a direct linkage to either the mobile banking location on your web site or to the mobile banking application itself.

6. Direct Mail. One of the best ways of educating the customers is the use of direct mail. Several banks are using direct mail as part of a multichannel strategy to increase ebanking penetration and usage.

7. Bank Communication through attending LGU's Meetings. There are obviously many ways to promote e-banking as well as many ways to offer incentives to the customer. The benefit of this is the ability to have dialogue with the customer around the advantages of using e-banking as well as providing a great opportunity to answer any questions or address any concerns the customer may have.

8. Traditional Media. While not used as extensively as other channels, traditional print advertisements such as banners, and fliers are still used to reinforce the benefits of ebanking. Usually focusing on deposit, rewards programs or new applications. This channel is an effective way to display market leadership in e-banking.

To remain competitive for the modern consumer, banks need to set aside a larger budget for online initiatives such as digital ads, content marketing and search engine optimization. These are investments that will lead to new customers and an increase in brand recognition. Brands should understand that putting digital marketing to work does not guarantee an overnight fix. It requires a long term strategy of building relationships with customers and integrating your company in the online world.

The above marketing strategies are the most effective things to do by any banking institutions if they want to have a lot of sales on their digital products.

\section{Discussion}

The respondents of the study are in their early and middle adulthood aging from 21 to 40. There were $58 \%$ female and $42 \%$ male respondents. On the one hand, the number of respondents is equally distributed in terms of the nature of work. Half of the respondents are employed while the other half are owners of small and medium enterprises. The respondents of the study agreed on all indicators of electronic banking services' reliability, convenience, safety and security, user-friendliness, error-freeness. Meanwhile, mean scores of the respondents' responses to one indicator of perceived speed and one indicator of perceived cost-effectiveness of e-banking services suggest the respondents' uncertainty. Nevertheless, the overall mean scores for these constructs (speed and costeffectiveness) were not at all affected as they are still within the range of scores which can be interpreted that the respondents agreed that e-banking services are fast and cost- 
effective. In general, the respondents' responses suggest that they have a positive view about e-banking services.

Through the one-way between-groups analysis of variance test, it was found out that there was no statistically significant difference at the $p<.05$ level in the perceived reliability, speed, safety and security, user-friendliness, cost-effectiveness, and errorfreeness across the respondents' five age groups (Group 1: 21 to 30 years old; Group 2: 31 to 40 years old; Group 3: 41 to 50 years old; Group 4: 51 to 60 years old; Group 5: Above 60 years old). However, there is a medium actual difference between the responses regarding the e-banking services' convenience of respondents coming from different age groups. Overall, the perceptions on online banking services of the respondents from different age groups do not significantly differ.

Meanwhile, determining whether or not gender is a factor in terms of the perception on e-banking services was also conducted using a two-sample z-test. It was found out that males' scores in all the seven constructs of perception on e-banking services (i.e. reliability, convenience, speed, safety and security, user-friendliness, cost-effectiveness, error-freeness) were not significantly different from the female respondents' scores. This suggests that gender is not a factor that may contribute to the difference in the perception on e-banking services.

Similar to gender, there was not enough evidence to support that nature of work (i.e. small or medium enterprise [SME] owner and employed) contributed significantly in the respondents' difference in perception on e-banking services. Utilizing two-sample z-test, it was found out that there was no significant difference between SME owners' and employed individuals' perceptions on e-banking services' reliability, convenience, speed, safety, user-friendliness, cost-effectiveness, and error-freeness. Further, their overall perception on e-banking services did not also differ significantly.

The results of the analysis showed that the regression model (consisting of technological, organizational, and environmental factors) does not significantly predict the respondents' perception on e-banking services' reliability, convenience, speed, safety and security, user-friendliness, cost-effectiveness, error-freeness.

The results showed that the respondents considered two of the nine given scenarios as challenges in their adoption of e-banking technologies. These are (1) their fear about the possible occurrence of electronic crimes and (2) the customers' preference for face-toface banking.

The top two recommendations given by the respondents in order to cope with the challenges they face in adopting e-banking technologies are (1) the improvement of Internet connection and (2) the conduct of trainings or orientation regarding e-banking services by banking institutions. The researcher presented the proposed network infrastructure in Figure 5 and marketing strategies to be considered by the bank to be able to educate customers in adopting e-banking technology. 
In light of the findings, the following conclusions were drawn: Most of the respondents are young and female. Half of the respondents are employed while the other half are owners of small and medium enterprises. This will help banking institutions in targeting customers in e-banking considering that many young female customers are involved in banking transactions, The respondents have a positive view about e-banking services which could be attributed to the trust and confidence of the respondents in the modern technological advancements in the country's banking institutions, Respondents are aware of and have a fair amount of understanding of the features of such technological advancements in e-banking regardless of their age, gender and nature of work, Despite the positive agreement of the respondents on the seven features of e-banking services (including safety and security), they are also concerned about the possible cybercrimes that may happen when they engage themselves in such kind of online transactions. The fear that they may be a victim of an online crime may be a reason why many bank customers still preferred face-to-face banking as they get to personally see the bank employee they are transacting to, Technological, organizational, and environmental factors that influence the respondents' adoption to e-banking services do not predict their perception on e-banking. Other factors that may significantly influence bank customers' understanding on the features and nature of online banking system could serve as a basis for individuals to use e-banking system do not necessarily match their perceived qualities of the system, Improvements of network infrastructure and promoting e-banking services are the top 2 priorities that the banking institutions should look into to fully appreciate and educate the customers in the whole region 3 , and Ebanking technology serves as a basis for developing a network infrastructure and marketing strategies.

Based on the findings and conclusions, the following recommendations are offered: Banking institutions may continuously improve their services (particularly in relation to their information technology and Internet facilities) in order to assure their bank clients and future customers of the reliability, convenience, speed, safety and security, userfriendliness, cost-effectiveness and error-freeness of the banks' online transactions and services. Upgrade in the e-banking facilities will be beneficial to both the banking institutions and the clients as they can be assured of the credibility and integrity of the banking system. This will also remove the fears of the bank clients in engaging more in online banking and instead encourage them to deal with the banks online. Future research may focus on a case study of a particular bank's performance in terms of its ebanking facility, an in-depth analysis of a bank's services may provide all the banking industry's stakeholders including the various bank companies and their clients more detailed description of the processes and problems that both the service providers and the customers experience and encounter. Through this, more appropriate and informed solutions will be provided to address specific e-banking-related concerns, and banking institutions must continuously promote e-banking technology through different strategies to educate more consumers in adopting e-business services. 


\section{References}

Abu-Shanab E, Pearson J. (2007) Internet banking in Jordan: The unified theory of acceptance and use of technology (UTAUT) perspective. Journal of Systems and information Technology 9: 78-97.

Ackha, D. (2014) Adoption of Electronic Banking in Ghana Banking System: A Case Study of Guaranty Trust Bank (Ghana) Limited. Retrieved dated March 1, 2017 from http://www.grin.com/en/e-book/284721/adoption-of-electronic-banking-in-ghanabanking-system.

Aliyu, A.A., Younus, S., Tasmin, R. (2012). An Exploratory Study on Adoption of Electronic Banking: Underlying Consumer Behaviour and Critical Success Factors. Case of Nigeria. Business and Management Review Vol.2(1) pp. 01-06 March, 2012 ISSN: 2047 -0398

AlSoufi, A. \& Hayat, A. (2014). Customers' perception of m-banking adoption in Kingdom of Bahrain: an empirical assessment of an extended TAM model. International Journal of Managing Information Technology (IJMIT) Vol.6, No.1.

Ahmed, A.K.E. (2009). E-Banking in UAE and Oman: Exploring consumer perception of satisfaction/dissatisfaction factors of e-banking services quality. Retrieved February 10, 2016 from http://bspace.buid.ac.ae/bitstream/1234/287/1/20040016.pdf

Bachelor, B. (2015). The history of e-banking. Retrieved from http://www.ehow.com/about_5109945_history-ebanking.html

Brown, T. A. (2016). Confirmatory factor analysis for applied research. New York: The Guilford Press.

Bruyn, A. D., and Lilien, G. L. (2014). A multi-stage model of word-of-mouth influence through viral marketing. International Journal of Research in Marketing. 25(3), pp. 151163.

Chandio F, Irani Z, Abbasi MS, Nizamani HA (2013) Acceptance of Online Banking Information Systems: An Empirical Case in a Developing Economy. Behaviour and Information Technology 32: 668-680.

Chaudhuri, A., Flamm, K. S., and Horrigan, J. (2015). An analysis of the determinants of internet access. Telecommunications Policy. 29(9-10), pp. 731-755.

Chen, I. J., Gupta, A., and Rom, W. (2012). A study of price and quality in service operations. International Journal of Service Industry Management. 5(2), pp. 23-4.

Colgate, M., and Hedge, R. (2011). An investigation into the switching process in retail banking services. International Journal of Bank Marketing. 19(4/5), PP. 201-213. 
Copeland, M. T. (2012). Relation of consumers' buying habits to marketing methods. Harvard Business Review. 1 (April), pp. 282-289.

Corbitt, B. J., Thanasankit, T., and Yi, H. (2013). Trust and e-commerce: a study of consumer perceptions. Electronic Commerce Research and Applications. 2(3), pp. 203215 .

Dabholkar, P. A., and Sheng, X. J. (2014). Perceived download waiting in using web sites: a conceptual framework with mediating and moderating effects. Journal of Marketing Theory and Practice. 16(3), pp. 259-270.

Dhurup, M., Surujlal, J., \&Redda,E. (2014). Customer perceptions of online banking service quality. Mediterranean Journal of Social Sciences. Vol 5 No 2. MCSER Publishing, Rome-Italy.

Easingwood, C. J., and Storey, C. (2011). Success factors for new consumer financial services. The International Journal of Bank Marketing. 9(1), pp. 3-10.

Featherman, M. S., and Pavlou, P. A. (2013). Predicting e-services adoption: a perceived risk facets perspective. International Journal of Human-Computer Studies. 59(4), pp. 451474.

Gao (2011). Characteristics and choices of Internet users. Washington, DC: United States General Accounting Office.

Gerrard, P., and Cunningham, J. B. (2013). The diffusion of internet banking among Singapore consumers. International Journal of Bank Marketing. 21(1), pp. 16-28.

GMA News On-line. (2011). PH online banking usage grows 39 percent. Retrieved February 4, 2016 from http://www.gmanetwork.com/ news/story/214577/scitech/phonline-banking-usage-grows-39-percent-y-o-y

Hiller, M. (2013). The role of cultural context in multilingual website usability. Electronic Commerce Research and Applications. 2(1), pp. 2-14.

Jacoby, J., and Kaplan, L. B. (2010). The components of perceived risk. Proceedings of the Third Annual Conference for Consumer Research, Association for Consumer Research (pp. 382-393)

Khalfan, A. \& Alshawaf, A. (2014). Adoption and Implementation Problems of E-Banking: A Study of the Managerial Perspective of the Banking Industry in Oman. Journal of Global Information Technology Management.

Lassar, W. M., Manolis, C., and Lassar, S. S. (2015). The relationship between consumer innovativeness, personal characteristics, and online banking adoption. The International Journal of Bank Marketing. 23(2/3), pp. 176-199. 
Lee, E. J., and Lee, J. (2011). Consumer adoption of Internet banking: need-based and/or skill based? The Marketing Management Journal. 11(1), pp. 101-113.

Lichtenstein, S., and Williamson, K. (2014). Understanding consumer adoption of internet banking: an interpretive study in the Australian banking context. Journal of Electronic Commerce Research. 7(2), pp. 50-66.

Luhmann, N. (2012). Familiarity, confidence, trust: problems and alternatives. In: Gambetta, D. G. (Ed.), Trust (pp. 94-107). New York: Basil Blackwell.

Maitlo GM, Kazi ZH, Khaskheley A, Shaikh FM (2015). Factors that Influence the Adoption of Online Banking Services in Hyderabad. Int J Econ Manag Sci 4: 216.

Mitchell, V. W. (2010). Consumer perceived risk: conceptualization's and models. European Journal of Marketing. 33(1/2), pp. 163-195.

Miyazaki, A. D., and Fernandez, A. (2011). Consumer perceptions of privacy and security risks for online shopping. Journal of Consumer Affairs. 35(1), pp. 27-44.

Mobarek, A. (2011). E-Banking Practices and Customer Satisfaction - A Case Study in Botswana. Retrieved from https://papers.ssrn.com/sol3/papers.cfm?abstract_id=1011112.

Moga, L.M., Md N.K., Neculita, M., \& Khani, N., (2012) . Trust and Security in E-banking Adoption in Romania: pp.1-10 <online> Available at http://rc4ht3qs8p.search.serialssolutions.com/? <Accessed 21st March 2012>

Mohr, L. A., and Bitner, M. J. (2010). The role of employee effort in satisfaction with service transactions. Journal of Business Research. 32(3), pp. 239-252.

Mojares, E.K. (2014). Customer satisfaction and loyalty among internet banking users of Philippine National Bank in Batangas City. Asia Pacific Journal of Multidisciplinary Research, Vol 2, No 2.

Murray, K. B., and Schlacter, J. L. (2010). The impact of services versus goods on consumers' assessment of perceived risk and variability. Journal of the Academy of Marketing Science. 18(1), pp. 51-65.

Novak, T. P., Hoffman, D. L., and Yung, Y. F. (2010). Measuring the customer experience in online environments: a structural modeling approach. Marketing Science. 19(1), pp. 22-42.

Palmer, J. W. (2012). Web site usability, design, and performance metrics. Information Systems Research. 13(2), pp. 151-167. 
Parisa, A (2016). Adoption of e-Banking Services by Iranian Customers.published Msc thesis. Lulea University of Technology, Division of Industrial Marketing and E-Commerce. Perkins, E.D., Annan, J. (2013). Factors affecting the Adoption of Online banking in Ghana: Implications for Bank Managers. International Journal of Business and Social Research (IJBSR), Volume -3, No.-6, June, 2013.

Rani, M. (2012). A study on the customer perception towards e-banking in Ferozepur district. International Journal of Multidisciplinary Research. Vol. 2, Issue. 1

Rajaraman, V. (2011). Essentials of e-commerce technology. PHI Learning Private Limited New Delhi.

Ren, F., and Kwan, Mei-Po. (2014). The impact of the Internet on human activity-travel patterns: analysis of gender differences using multi-group structural equation models. Journal of Transport Geography. 17(6), pp.440-450.

Redlinghuis, A. (2010). Customer perceptions on Internet banking information protection. South African Journal of Information Management. AOIS Publishing.

Rossiter, J. R., and Percy, L. (2012). Advertising and Promotion Management. New York: McGraw Hill.

Schiffman, L.G., and Kanuk, L. L. (2012). Consumer behaviour (6th ed.). Upper Saddle River, NJ: Prentice Hall.

Skundirc, N. \&Milutinoric, V. (2003). E-banking. Retrieved February 2, 2016 from http://home.etf.rs/ vm/os/epos/e-bank.ppt

Suping, H., \&Yizheng, S.,(2010) Factors influencing user acceptance of online banking.1: pp.315-318. [online] Available from: IEEEXplorehttp://ieeexplore.ieee.org.libaccess.hud.ac.uk/stamp/ stamp.jsp?tp=\&arnumber=5461412 <Accessed 4 June 2012>

Tarhini A, Mgbemena C, Trab MSA, Masa'deh R (2015) User Adoption of Online Banking in Nigeria: A Qualitative Study. J Internet Bank Commer 20:132.

Voli, P. K. (2010). The convenience orientation of services consumers: an empirical examination. Published doctoral dissertation. Old Dominion University, Virginia, United States of American.

Ward, M. R., and Lee, M. J. (2010). Internet shopping, consumer search and product branding. Journal of Product and Brand Management. 9(1), pp. 6-20.

Xue M, Hitt LM, Chen PY (2011) Determinants and outcomes of internet banking adoption. Management Science 57: 291-307. 
Yang, Z., Cai, S. H., and Zhou, N. (2015). Development and validation of an instrument to measure user perceived service quality of information presenting Web portals. Information \& Management. 42(4), pp.575-589.

Yousafzai SY (2012)A literature review of theoretical models of Internet banking adoption at the individual level. Journal of Financial Services Marketing 17: 215-226.

Yu, C.S., and Lo, Y. F. (2014). Factors encouraging people to adopt online banking and discouraging adopters to use online banking services. Proceeding of Business and Information. Tokyo, Japan: International Conference on Business and Information.

Zeithaml, V. A., and Bitner, M. J. (1996). Services marketing. New York: McGraw-Hill.

Zeithaml, V. A. (2010). Customer perceptions of price, quality and value: a means-end model and synthesis of evidence. Journal of Marketing. 52(July), pp. 2-22.

$x x x x x x x x-----x x x x x x x x$ 